\title{
Impact of the body waves on the serpentine structure
}

\section{Въздействието на механичните обемни вълни върху структурата на серпентина}

\section{Evgenia Kozhoukharova \\ Евгения Кожухарова}

Geological Institute, Bulgarian Academy of Sciences, 1113 Sofia, Bulgaria; E-mail: ekozhoukharova@abv.bg

\begin{abstract}
A rare case of rhythmic banded eclogitization on serpentinites in crustal condition (3 km south of Avren village, Krumovgrad district), is interpreted as an effect of seismic impact. Bands of garnet lherzolites $(2-5 \mathrm{~cm})$ alternate with strips of unchanged serpentinite. The bands consist of pyrope, diopside, enstatite, olivine, spinel, crystallized at T $560-820^{\circ} \mathrm{C}$ and $\mathrm{P} 8-15 \mathrm{kbar}$. The longitudinal P-waves create zones of dilatation in the serpentine structure where the bonds were broken. After crystallization of mobilized particles a stripped texture was formed.
\end{abstract}

Keywords: body waves, serpentine, eclogitization, Rhodope Massif.

\section{Увод}

Във физиката е известно, че триенето между две тела създава механични обемни вълни, които активизират вибрациите на атомите и предизвикват вътрешни и външни деформации на телата. Вълните са пряко свързани и с геоложките процеси. Досега обаче те са разглеждани само в аспекта на сеизмотектониката и съвременните знания за ролята на механичните вълни в петроложките, в частност метаморфните процеси, са крайно оскъдни. Целта на съобщението е с един илюстративен пример да насочи вниманието към въздействието на механичните обемни вълни върху структурата на серпентина и еклогитизацията на серпентинитите.

\section{Сыщност и действие на механичните обемни вълни}

Всяко триене в трите си модификации: плъзгане, търкаляне и удар, предизвиква поява на механични обемни вълни, известни в геофизиката като сеизмични вълни. Те са два вида: надлъжни P- и напречни S-вълни, които увеличават вибрационната амплитуда на градивните частици в кристалната решетка. При надльжните Р-вълни те трептят по посоката на разпространение на вълната и се създава редуване на пространства на разширение (дилатация) с разреждане на частиците и пространства на компресия със сгъстяване на същите. В случаи на силно отклонение на частиците от равновесната им точка в зоната на дилатация настьпва скъсване на връзките и преминаването им в свободно хаотично състояние, т.е. стопяване. Подобно явление е напълно възможно при серпентина, където слабите Ван дер Ваалсови връзки могат лесно да се прекъснат в пространствата на разширение. Разрушаване на структурата на минералите вследствие сеизмичните вълни е установено при големи земетресения в Япония. По време на земетресението в Кобе (1995 г.) в епицентъра са наблюдавани необичайни светлинни, електрични, радиоактивни явления, както и електронни екзоемисии, приети като доказателство за разрушаване на минералната структура на скалите в хипоцентьpa (Enomoto et al., 2001; Enomoto, 2005). Brantut et al. (2016) успяват да докажат експериментално увреждането на кристалната структура под влиянието на сеизмичните вълни. В лабораторни условия те създават микросеизмични вълни и подлагат на тяхното въздействие образец от антигоритов серпентинит. Установяват косеизмично плъзгане и значително повишаване на температурата на асперитите, което довежда до аморфизиране и частично топене по фрикционната повърхност. Освен това, във вътрешната структура на антигорита се регистрира поява на слой от 1 до $3 \mu \mathrm{m}$ от „пенеста“ т.е., полутечна материя, указание за дълбоко проникване на вълните и разрушение на кристалната структура. Изборът на серпентин като експериментален материал е предпочетен заради структурните му особености. 


\section{Структура на серпентина}

Серпентинът е широко разпространен минерал в континенталната Земна кора, попаднал там по тектонски път. Образува се във водни басейни при хидратацията на оливин-пироксенови перидотити. Изгражда серпентинитови тела в офиолитовите асоциации, както е и в кристалинния комплекс на Родопския масив (Kozhoukharova, 2019).

Структурата на серпентина е слоеста $(1: 1)$. При характеристиката на структурата е приета терминологията, предложена от Д. Стефанов (Stefanov, 1986), която е превод на предложенията на Номенклатурната комисия към AIPEA от 1972 г. и съответства по категории на актуалната, използвана в англоезичната литература (Evans et al., 2013). Всеки слой (layer) се състои от 2 мрежи (sheets) силиций-кислород тетраедрична и магнезий-кислород (брусит) октаедрична, свързани с ковалентни връзки, докато слоевете 1:1 са свързани със слаби водородни връзки. Поради 3-5\% геометрично несъответствие на двете мрежи (sheets) октаедричната (магнезий-кислородна) мрежа показва слаба вълнистост, което още повече отслабва връзката между слоевете. Серпентинът е известен в три модификации: лизардит, хризотил и антигорит. Най-високотемпературната от тях - антигоритьт започва да се разрушава частично чрез дехидратация при $300-350{ }^{\circ} \mathrm{C}$, достигайки пределна стабилност в лабораторни условия до $640{ }^{\circ} \mathrm{C}$ (Evans et al., 2013), като се замества последователно от талк и оливин, а при наличие на $\mathrm{Al}$ и $\mathrm{Ca}-$ и от пироксени. В контакт с богата на $\mathrm{SiO}_{2}$ среда, например, пегматит-аплитови жили, протичат бързи реакции на заместване и възникват разнообразни хибридни скали: дайкоподобни метасоматични габроиди, тела от корона-габро и др. Механичните обемни Р-вълни, причиняват разкъсване на връзките и освобождаване на градивните частици на серпентина, респективно серпентинита, в отделни слоеве, последвано от кристализация на стопената материя, което в краен резултат довежда до възникване на нови скали като ивичестите гранатови лерцолити.

\section{Ивичести гранатови лерцолити в серпентинити от Родопския масив}

Рядък случай на възникване на ивици от гранатови лерцолити сред антигоритови серпентинити е установен в серпентинитово тяло от Пъстрата свита на Родопската група, разположена в Авренската синклинала на Източните Родопи (Kozhoukharova, 1996). Тялото е в стрьмен до вертикален контакт с лептитови гнайси, който е част от почти север-южна тектонска система, продължаваща на територията на Северна Гърция. Периферната част на серпентинитовото тяло (30-40 m) е засегната от еклогитизация, представена в ивици $(2-5 \mathrm{~cm})$ от гранатови лерцолити, които се редуват с ивици от непроменени серпентинити (фиг. 1). Ивиците постепенно изчезват към вътрешността на серпентинитовото тяло. Те са паралелни на контакта и на общата стратификация на вместващите скали.

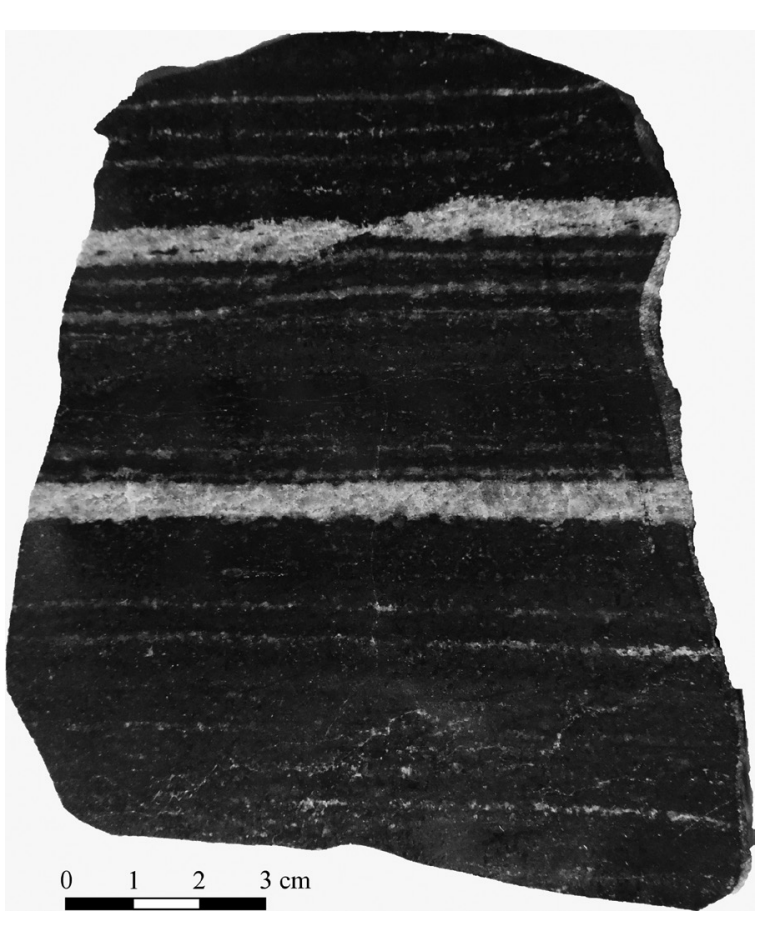

Фиг. 1. Ивичест серпентинит. Тъмните ивици - серпентинит, светлите - еклогитова минерализация от пироп, диопсид, енстатит, оливин и шпинел.

Лерцолитовите ивици се състоят от пироп, диопсид, енстатит, оливин и шпинел, кристализирали при Т $560-820{ }^{\circ} \mathrm{C}$ и $\mathrm{P} 8-15 \mathrm{kbar}$, докато общия метаморфизъм на околните скали е в среднобаричен амфиболитов фациес (Т $480-540{ }^{\circ} \mathrm{C}$, P 4-6 kbar), показвайки пространствена хетерофациалност.

\section{Дискусия}

Търсейки правдоподобно обяснение за възникването на гранат-лерцолитовите ивици сред серпентинитите, подчертаваме основните им характеристики

- контактьт между серпентинитовото тяло и лептитовите гнайси носи чертите на стара консолидирана сеизмотектонска зона; 
- периферното разположение и конформност на лерцолитовите ивици към общата стратификация изключва възможността те да са реликтови кумулати от магмения стадий на ултрабазитите и ги утвърждава като метаморфни образувания, наложени върху серпентинитите;

- ритмичното редуване на лерцолитовите ивици с непроменени серпентинитови, съответства на картината, създавана от надлъжните Р-сеизмични вълни, където в пространствата на дилатация кристалохимичните връзки се скъсват и се появяват слоеве от разтопен материал;

- слабите Ван дер Валсови връзки в серпентина благоприятстват развитието на подобен процес на разрушение на структурата на антигорита, вследствие на механичните обемни (сеизмични) вълни.

Липсват преки данни за възрастта на еклогитовата минерализация. Остава открит въпросът дали тя е синхронна на регионалния метаморфизъм или по-късна от него. Доколкото обаче еклогитизацията е проявена по тектонска зона, съвпадаща със север-южната посока на постметаморфните структури, възможно е тя да е създадена също след регионалния метаморфизъм. Най-вероятно по тази зона се е състояло сеизмотектонско събитие, произвело механични обемни Р- и S-вълни. Те са разрушили серпентина в пространствата на дилатация, последвано от кристализация на еклогитовата парагенеза и възникване на специфичната ритмична ивичеста текстура на еклогитизирания серпентинит.

\section{Заключение}

Разрушаващото въздействие на сеизмичните вълни върху структурата на серпентина теоре- тично е напълно обосновано и експериментално доказано. Посоченият природен пример с гранатови лерцолити визуализира деформации, образно подобни на сеизмичните вълнови деформации и подкрепя правдоподобността на една хипотезата за сеизмично-вълновия произход на ивичестите еклогитизирани серпентинити от Авренския район на Източните Родопи. Същевременно, развитието на подобна високотермобарична минерална асоциация върху серпентинити от метаморфен комплекс е доказателство за възможността еклогитизацията да възниква в пределите на кората при сеизмотектонски събития, а не в дълбочинни подкорови нива.

\section{Литература \\ References}

Brantut, N., F. X. Passelègue, D. Deldicque, J.-N. Rouzaud, A. Schubnel. 2016. Dynamic weakening and amorphization in serpentinite during laboratory earthquakes. - Geology, 44, $8,607-610$.

Enomoto, Y. 2005. Geotribology of earthquakes. - Japan. J. Tribology, 50, 5, 513-521.

Enomoto, Y., F. Asuke, Zh. Zheng, H. Ishigaki. 2001. Hardened foliated fault gouge the Nojima Fault Zone at Hirabayashi: Evidence for earthquake lightning accompanying the 1995 Kobe earthquake? - Island Arc, 10, 447-456.

Evans, B. W., K. Hattory, A. Baronnet. 2013. Serpentinite: What, why, where? - Elements, 9, 99-106.

Kozhoukharova, E. 1996. Eclogitized layered serpentinites in the East Rhodope block. - C. R. Acad. Bulg. Sci., 49, 6, 69-71.

Kozhoukharova, E. 2019. Obducted serpentinites in the Rhodope Massif and their stratigraphic, paleotectonic and metamorphic significance. - Rev. Bulg. Geol. Soc., "Geosciences 2019", 80, 3, 72-74.

Stefanov, D. 1986. Classification scheme and nomenclature of layered silicates, including clay minerals. - Rev. Bulg. Geol. Soc., 47, 3, 115-121 (in Bulgarian with English abstract). 